\title{
Stanovení velmi nízkých objemových aktivit tritia pro potřeby využití tritia jako stopovače
}

\section{DIANA MAREŠOVÁ, EDUARD HANSLÍK, EVA JURANOVÁ, BARBORA SEDLÁŘOVÁ}

\author{
Klíčová slova: tritium - srážky - povrchová voda - LSC - elektrolytické nabohacení
}

\section{SOUHRN}

$\checkmark$ současnosti jsou hlavními zdroji tritia $\vee$ životním prostředí přetrvávající dopady atmosférických testů jaderných zbraní v minulém století, tritium vypouštěné jadernými zařízeními a jeho přirozená produkce v atmosfére. Díky jeho všeobecné prítomnosti a príznivým vlastnostem je tritium ve formě HTO využiváno jako stopovač v podzemních a povrchových vodách. Od ukončení atmosférických jaderných testů obsah tritia ve srážkách klesá a postupně se blízí přirozeným koncentracím pod $1 \mathrm{~Bq} / \mathrm{l}$. V této souvislosti je třeba citlivé metody stanovení. Článek popisuje vývoj objemové aktivity tritia v povodí Labe v lokalitách bez prímého vlivu antropogenních emisí tritia v období 2001-2017. Vyhodnocené úrovně jsou výchozím podkladem pro využití tritia jako stopovače, např. v oblasti hydrogeologického modelování.

\section{ÚVOD}

Tritium $\left({ }^{3} \mathrm{H}\right)$ je radioaktivní izotop vodíku s poločasem preměny $12,32 \mathrm{r}$, resp. $4500 \pm 8$ d [1], který se přirozeně vyskytuje $\vee$ množství 1 atom na $10^{18}$ atomů vodíku. Tritium přirozeně vzniká jadernými reakcemi vyvolanými kosmickým zářením $v$ horních vrstvách atmosféry, patři mezi tzv. kosmogenní radionuklidy [2]. Roční kosmogenní produkce tritia je odhadována na $72 \mathrm{PBq} / \mathrm{r}$ $\left(72 \cdot 10^{15} \mathrm{~Bq}\right)$, což odpovídá přirozenému konstantnímu výskytu tritia $v$ atmosfére přibližně $1275 \mathrm{PBq}$ [3]. Přirozená úroveň tritia ve srážkách v oblasti střední Evropy je odhadována na 5 TU [4]. Tritiové jednotky (TU) jsou odvozeny z přirozené koncentrace tritia. Pro převod hodnot uvedených $\vee$ TU platí vztah $1 \mathrm{TU}=0,11919 \pm 0,00021 \mathrm{~Bq} / \mathrm{kg}$ [5]; 5 TU je tedy približně 0,6 Bq/l. Hanslík [6] na základě dřivějších odhadů uvádí pro přirozenou úroveň tritia ve srážkách hodnotu 0,38 Bq/l.

Uměle je produkováno tritium zejména v důsledku využívání jaderné energie at' už pro mírové, nebo vojenské účely. V jaderném reaktoru vzniká tritium při štěpných procesech (ternární štěpení) a aktivačních procesech v konstrukčních materiálech, chladivu a moderátoru. Doposud největším zdrojem tritia $\checkmark$ atmosfére, který je stále měřitelný, však byly testy jaderných zbraní v padesátých a šedesátých letech minulého století. Množství tritia uvolněného v průběhu testů do atmosféry se odhaduje na $186 \mathrm{EBq}\left(186 \cdot 10^{18} \mathrm{~Bq}\right)$ [3]. Většina testů probíhala na severní polokouli. Jen asi $5 \%$ uvolněného tritia se vlivem stratosférické cirkulace dostalo na jižní polokouli [7]. Objemová aktivita tritia ve srážkách v době kulminace atmosférických testů byla na severní polokouli približně 600 Bq/l [4]. Od zákazu atmosférických jaderných testů v roce 1963 dochází k postupnému poklesu globální úrovně tritia $v$ životním prostředí. Z uváděných dat [3] můžeme odhadnout príspěvek tritia z jaderných testů $\vee$ globálním inventáři pro rok 2016 na 9,6 EBq, po roce 2050 bude príspěvek srovnatelný s množstvím tritia přirozeného pưvodu (1,3EBq). Ve srovnání s atmosférickými testy jaderných zbraní jsou ostatní antropogenní zdroje tritia v globálním měřítku minoritní a mají spíše lokální význam [8]. Napríklad UNSCEAR uvádí roční celosvětovou výpust tritia do ovzduší v devadesátých letech na úrovni jednotek PTBq $\left(10^{15} \mathrm{~Bq}\right)$ a celosvětovou roční výpust do vodotečí na úrovni 10 PTBq [3].

Tritium přirozeného původu i původem z jaderných testů se $v$ atmosféře vyskytuje dominantně ve formě HTO. K zemskému povrchu se dostává nejvíce během jara a léta. Je to zpưsobeno jarním zeslabením tropopauzy, kdy dochází k průniku stratosférického vzduchu do troposféry. Tomu odpovídá i cyklický průběh koncentrací tritia ve srážkách. Na severní polokouli se jedná o zvýšené hodnoty v období jaro-léto a nejnižší v zimě [9].

Vzhledem k výše uvedeným skutečnostem je tritium v chemické formě HTO využíváno jako stopovač pro podzemní a povrchové vody. Např́klad pro modelování transportu polutantů v toku pod jadernou elektrárnou [10, 11], v podzemních vodách [12,13], také se používá k určování stárí a původu podzemních vod. Pro všechny tyto účely je základním předpokladem přesné stanovení nízkých objemových aktivit tritia.

Objemová aktivita tritia ve srážkách je závislá především na zeměpisné šiřce a vzdálenosti lokality od oceánu. Současná úroveň aktivity tritia ve srážkových vodách ve středním zeměpisném pásmu severní polokoule $v$ kontinentálních podmínkách je přibližně $1 \mathrm{~Bq} / \mathrm{l}$. V podzemních vodách jsou ojediněle zjištovány vyšší koncentrace až několik Bq/I původem ze srážek v období jaderných testů. Na jižní polokouli je to $z$ důvodu omezené výměny vzduchu přes rovníkové pásmo v době vrcholících testů jaderných zbraní méně, přibližně 0,1-0,5 Bq/I [14].

Pro Českou republiku nebylo publikováno mnoho souhrnných údajů o objemových aktivitách tritia v životním prostředí, které by byly využitelné pro výše uvedené modely. Existuje celosvětová sít, která zveřejňuje údaje o izotopech včetně tritia ve srážkách a povrchových vodách (Global Network of Isotopes in Precipitation and Rivers, GNIP, resp. GNIR) $[15,16]$, kterou zajištujuje Mezinárodní atomová agentura se sídlem ve Vídni. Do této sítě přispěla údaji z České republiky pouze jedna stanice srážkových a povrchových vod (stanice Uhliřská v Jizerských horách), a to za období 2006-2010, resp. 2006-2012. Údaje o objemové aktivitě tritia ve srážkách a povrchových vodách na území České republiky v lokalitách prímo neovlivněných provozem jaderných elektráren v předešlém období publikovali např́ílad autoři viz [6, 17-19].

Tento př́spěvek se zaměřil na vývoj aktivit tritia ve srážkách a povrchových vodách bez prímého vlivu jaderných zařízení v Čechách, resp. v povodí Vltavy a Labe. Hlavním cílem bylo vyhodnotit aktuální úroveň aktivity tohoto radionuklidu. Stanovení tritia bylo prováděno podle ČSN EN 9698 [20], od roku 2010 byly vzorky předupravovány elektrolytickým nabohacením. 
Tabulka 1. Základni charakteristika odběrových mist

Table 1. Characteristics of sampling sites

\begin{tabular}{llll} 
Povrchová voda & $\begin{array}{l}\text { Dlouhodobý } \\
\text { průměrný } \\
\text { průtok }\left(\mathrm{m}^{3} \cdot \mathrm{s}^{-1}\right)\end{array}$ & $\begin{array}{l}\text { Počet } \\
\text { vzorků } \\
\text { za rok }\end{array}$ \\
\hline 1 & Vltava-Hluboká & 27,6 & 12 \\
\hline 2 & Labe-Lysá & 74,1 & 12 \\
\hline 3 & Vltava-Hněvkovice & 30,6 & 4 \\
\hline 4 & Lužnice-Koloděje & 24,1 & 4 \\
\hline 5 & Otava-Topělec & 23,3 & 4
\end{tabular}

\begin{tabular}{llll}
\multicolumn{2}{l}{ Srážky } & Období sledování \\
\hline A & Praha-Podbaba & $2001-2017$ & 12 \\
\hline B & Kocelovice & $2006-2017$ & 12 \\
\hline C & Přimda & $2001-2005$ & 12 \\
\hline D & Lužnice & $2001-2012$ & 12 \\
\hline E & Závišín & $2001-2005$ & 12
\end{tabular}

\section{METODIKA}

Vzorky srážek byly odebírány jedenkrát měsíčně (směsný měsíční vzorek) v lokalitách Praha-Podbaba, Kocelovice, Přimda, Lužnice nad Lužnicí, Závišín, podrobnosti jsou uvedeny $v$ tabulce 1. Vzorky povrchových vod byly odebírány jedenkrát měsičně v profilech Vltava-Hluboká a Labe-Lysá a čtvrtletně v profilech VItava-Hněvkovice, Lužnice-Koloděje a Otava-Topělec v období 2002-2017 (tabulka 1, obr. 1).

Tritium bylo stanoveno podle ČSN EN 9698 [20]. Vzorky byly predupraveny destilací a měřeny v prístroji Quantulus 1220, od roku 2010 byly vzorky nejprve elektrolyticky nabohaceny (výchozí objem vzorku 0,5 I). Měřena byla směs $8 \mathrm{ml}$ vzorku a $12 \mathrm{ml}$ scintilačního koktejlu Ultima Gold LLT. K omezení chemiluminiscence byl vzorek před měřením uchováván 12 hodin $v$ temnu. Doba měření byla 800 minut, v prípadě nabohacených vzorků 300 minut. Ke kalibraci byl použit certifikovaný referenční materiál od ČMI. Jako slepý vzorek byla použita artézská voda z dlouhodobě sledovaného zdroje s aktivitou menší než $0,07 \mathrm{~Bq} / \mathrm{l}$. Nejistota měření a nejmenší detekovatelná aktivita $\left(c_{\mathrm{ND}}\right)$ na hladině významnosti 95 \% byla vyjádřena podle ČSN 757600 [21]. U vzorků bez elektrolytického nabohacení byla $\mathrm{C}_{\mathrm{ND}}$ cca $1 \mathrm{~Bq} / \mathrm{l}$, pro vzorky nabohacené $0,07 \mathrm{~Bq} / \mathrm{l}$.

Hodnoty menší než $\mathrm{C}_{\mathrm{ND}}$ byly do dalšího zpracování zahrnuty na úrovni $\mathrm{C}_{\mathrm{ND}}$. Průměrné hodnoty tritia ve srážkách byly vážené množstvím srážek na konkrétní stanici. rádu:

Pro popis poklesu objemových aktivit tritia byla použita rovnice prvního

$$
\ln C_{j}=-\lambda_{e f} \cdot t+\ln C_{0}
$$

c. je roční průměrná objemová aktivita tritia $\vee$ povrchové vodě nebo srážkách v roce j (Bq/l),

$\lambda_{\text {ef }} \quad$ efektivní (pozorovaná) konstanta ubývání (1/r)

t doba sledování.
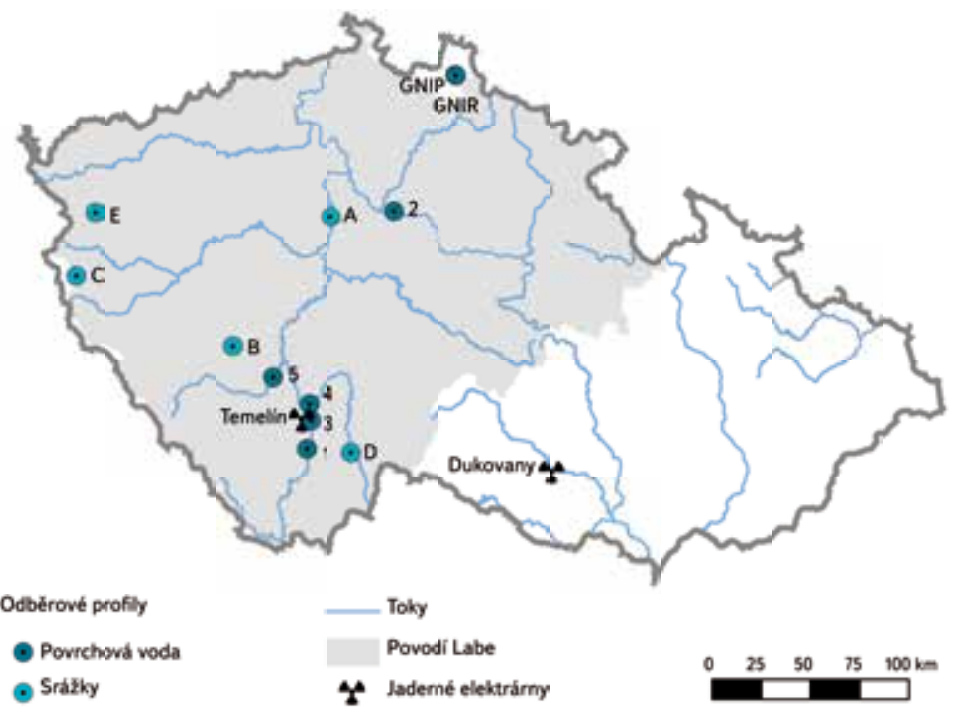

Obr. 1. Mapa odběrových míst vzorků v povodí Vltavy a Labe Fig. 1. Map of sampling sites

Statistická významnost závislosti byla ověřena pomocí Pearsonova koeficientu. S použitím efektivní konstanty byl vypočten pozorovaný poločas poklesu aktivity $T_{\text {ef }}(r)[22]$ :

$$
T_{e f}=\ln 2 / \lambda_{e f}
$$

Pro zjištění sezonních změn tritia ve srážkách byly vypočteny průměrné hodnoty vážené množstvím srážek pro jednotlivá roční období. Pro výpočet byly jako jaro vzaty měsíce březen-květen, léto červen-srpen, podzim září-listopad a zima měsíce prosinec až únor [23].

\section{VÝSLEDKY A DISKUSE}

Vývoj objemové aktivity tritia $\vee$ povrchové vodě vyhodnocené jako průměr z profilů neovlivněných prímými výpustmi jaderného zařízení je zachycen na obr. 2. Na obrázku jsou data porovnána s výsledky pro české území publikovanými dř́ve a dále s profily uvedenými v databázi GNIR. Jednak byly použity profily v Německu, které svojí geografickou polohou a klimatickými podmínkami odpovídají našim podmínkám, a dále výsledky z jediné české stanice zapojené v GNIR.

Vyhodnocené roční průměrné objemové aktivity $v$ povrchové vodě $v$ hodnoceném území byly v období 2002-2017 v rozmezí 0,87-1,43Bq/l.

Vývoj vážených ročních průměrných objemových aktivit tritia ve srážkách $\checkmark$ české části povodí Labe je uveden na obr. 3. V grafu je uvedeno i srovnání s výsledky publikovanými dřive pro české území a s daty uvedenými v GNIP. Vyhodnocené vážené roční průměrné aktivity v hodnoceném období 2001-2017 byly $\vee$ rozmezí 0,94-1,38 Bq/l.

Pozorované roční průměrné objemové aktivity tritia ve srážkách a povrchové vodě jsou přibližně $1 \mathrm{~Bq} / \mathrm{l}$ a jsou srovnatelné s výsledky uváděnými v databázích GNIR a GNIP pro stanice ve srovnatelných geografických podmínkách (severní polokoule, střední zeměpisná šírka, kontinentální charakter). Tyto aktivity jsou stále vyšší, než je úroveň tritia odpovídající přirozenému pozadí tritia a než aktivity pozorované na jižní polokouli, kde se úroveň tritia dostala přibližně na úroveň charakteristickou pro období před jadernými testy [7, 14, 24].

$S$ použitím rovnice (1) byl hodnocen trend poklesu ročních průměrných objemových aktivit tritia v povrchových vodách i srážkách. V prípadě povrchových vod byl pro období 2001-2017 nalezen statisticky významný trend poklesu, ovšem s poločasem vypočteným podle rovnice (2) $28,3 \pm 9,0$ let, což je hodnota 


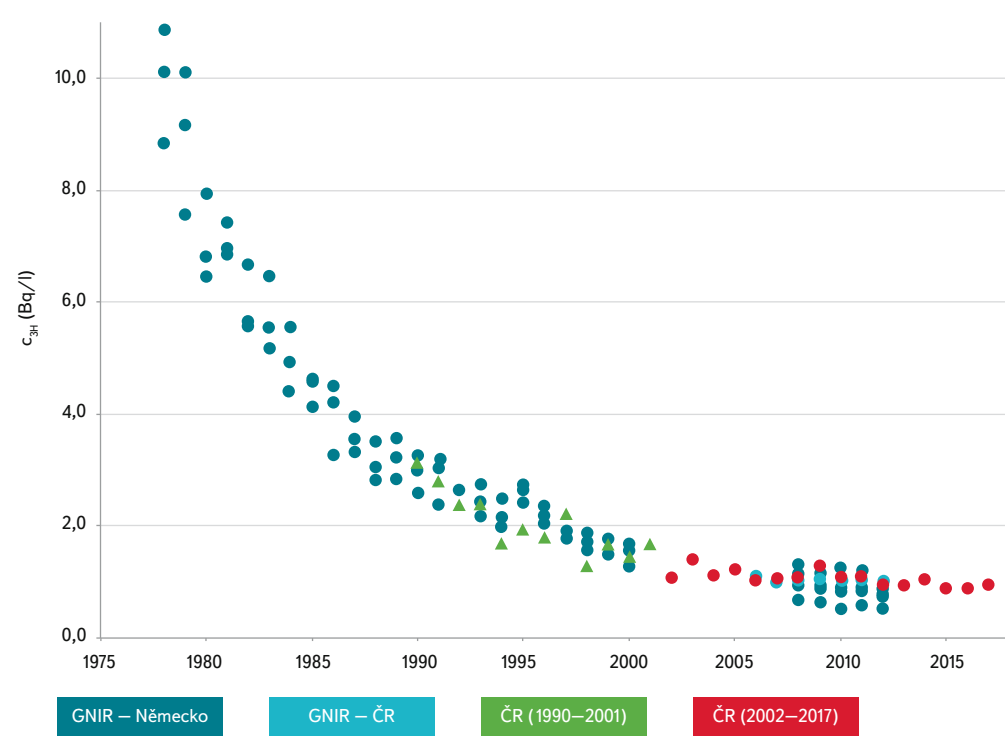

Obr. 2. Vývoj objemových aktivit tritia v povrchových vodách na území povodí Labe ve srovnání s dřive publikovanými výsledky pro ČR a s daty uvedenými v GNIR (Německo, ČR) Fig. 2. Comparison of tritium concentrations in surface water in Elbe River Basin with data from GNIR and previously published data for the Czech Republic

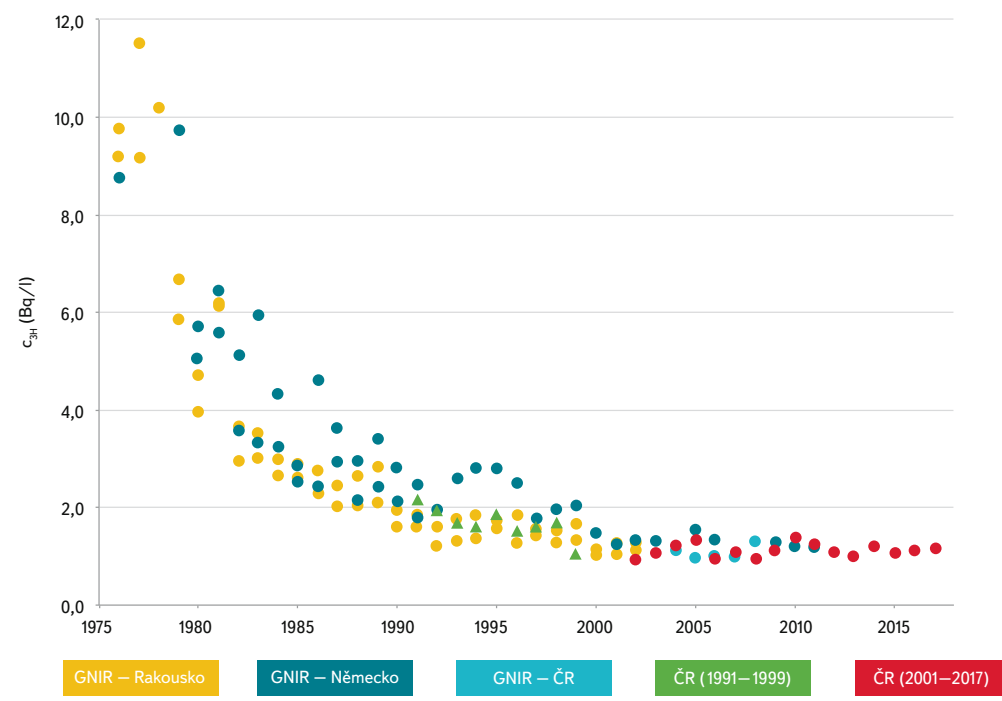

Obr. 3. Vývoj objemových aktivit tritia ve srážkách na území povodí Labe ve srovnání s dřive publikovanými výsledky pro ČR a s daty uvedenými v GNIP (Německo, Rakousko, ČR) Fig. 3. Comparison of tritium concentrations in precipitation in Elbe River Basin with data from GNIP and previously published data for the Czech Republic

významně vyšší, než je poločas přeměny tritia 12,32 let [1]. Dưvodem mohou být současné zdroje tritia: a) antropogenní, zejména jaderné elektrárny v ČR a v zahraničí (ze kterých se k nám dostává atmosférickým přenosem), b) přirozená produkce tohoto radionuklidu. Korekce pro výpočet poločasu poklesu aktivity (odpovídající hodnotě objemové aktivity pro stabilní príisun tritia z těchto zdrojů) byla odhadnuta na základě publikovaných údajů. Podle autorů publikace [5] činila tato hodnota 0,48 Bq/l (0,38 Bq/l odhadovaná aktivita odpovídající príirozené produkci a 0,1 Bq/l aktivita odpovídající prenosu tritia z jaderných elektráren), podle údajů z publikace [4] byla použita hodnota 0,6 Bq/l (autoři uvádí pro odhad odpovídající pouze přirozené produkci). Vypočtené hodnoty efektivních poločasů poklesu aktivity pak byly 15,9 \pm 4,8 let podle [6] a 12,7 $\pm 3,7$ let podle [4], jak je uvedeno $\vee$ tabulce 2 . S prrihlédnutím $k$ nejistotám vypočtených poločasů jde v obou prípadech o hodnoty odpovídající přibližně poločasu přeměny tritia. Pro území České

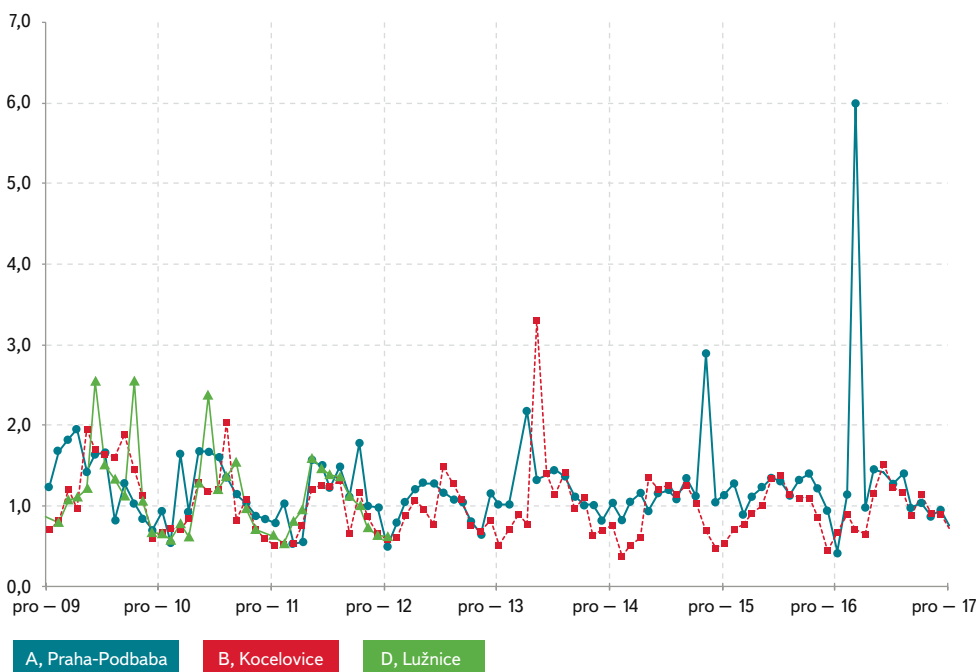

Obr. 4. Vývoj objemové aktivity tritia ve srážkách na vybraných profilech v období 2010-2017 Fig. 4. Tritium concentrations in precipitation from selected monitoring sites in the period 2010-2017

republiky se jeví jako přesnější odhad vycházející z rovnovážné hodnoty objemové aktivity 0,6 Bq/l, jelikož je zatížen menší nejistotou. Z výpočtu vyplývá, že př́spěvek jaderných elektráren na našem území je velmi malý a v rámci nejistot jej můžeme zanedbat. V budoucnu ovšem s rozvíjející se světovou jadernou energetikou a dalším poklesem „bombového" tritia může jeho význam narůst.

Obdobně byl analyzován trend poklesu objemových aktivit tritia ve srážkách. V období po roce 2002 nebyl pozorován statisticky významný trend poklesu objemových aktivit tritia ve srážkách ani při analýze korigovaných hodnot jak postupem podle [6], tak i [4], který byl pozorován v předchozích obdobích (obr. 2 a 3), v České republice ještě v devadesátých letech [6].

Dále byla hodnocena sezonní variabilita tritia ve srážkách v období 2010-2017, kdy byly vzorky ze stanic Praha-Podbaba, Kocelovice a Lužnice (sledování ukončeno 2012) elektrolyticky nabohaceny. Průběh objemových aktivit na těchto stanicích je uveden na obr. 4. U 85 \% zjištěných hodnot bylo rozmezí 0,5-1,5Bq/l, jen asi $4 \%$ z celkového počtu hodnot přesáhlo 2 Bq/l (přesná prríčina odlehlých hodnot nebyla zkoumána).

Byly hodnoceny průměrné hodnoty objemových aktivit (vážené srážkovými úhrny) pro jednotlivá roční období, které jsou zobrazeny na obr. 5. Vyšší průměrné hodnoty byly pozorovány v jarním a letním období, nejnižší v zimě. Sezonní variabilita tritia ve srážkách souvisí s pohyby vzdušných mas, kdy v důsledku ohřevu kontinentů dochází k vzestupu tropopauzy nejvíce v jarním období a k průniku stratosférického vzduchu s vyšším obsahem tritia k zemskému povrchu [25].

Tabulka 2. Vypočtené efektivni poločasy (bez a s korekcí o př́spěvek tritia prrirozeného pưvodu, prípadně prenosem z jaderných zařizeníjinde ve světě)

Table 2. Evaluated effective half-lives of tritium concentration decrease in surface water (without and with correction for the natural component and the contribution from nuclear facilities worldwide) in the period 2002-2017

$\begin{array}{lll}\text { Povrchová } & 1, & 2, \\ \text { voda, průměr } & \text { Vltava-Hluboká } & \text { Labe-Lysá }\end{array}$

( $r)$

\begin{tabular}{lllllll}
\hline$T_{\text {ef }}$ & 28,3 & $\pm 9,0$ & 29,8 & $\pm 13,1$ & 26,7 & $\pm 14,5$ \\
\hline$T_{\text {ef }}(\operatorname{kor}[5])$ & 15,9 & $\pm 4,8$ & 16,9 & $\pm 7,7$ & 14,6 & $\pm 9,1$ \\
\hline$T_{\text {ef }}(\operatorname{kor}[4])$ & 12,7 & $\pm 3,7$ & 13,5 & $\pm 6,4$ & 11,7 & $\pm 8,7$
\end{tabular}




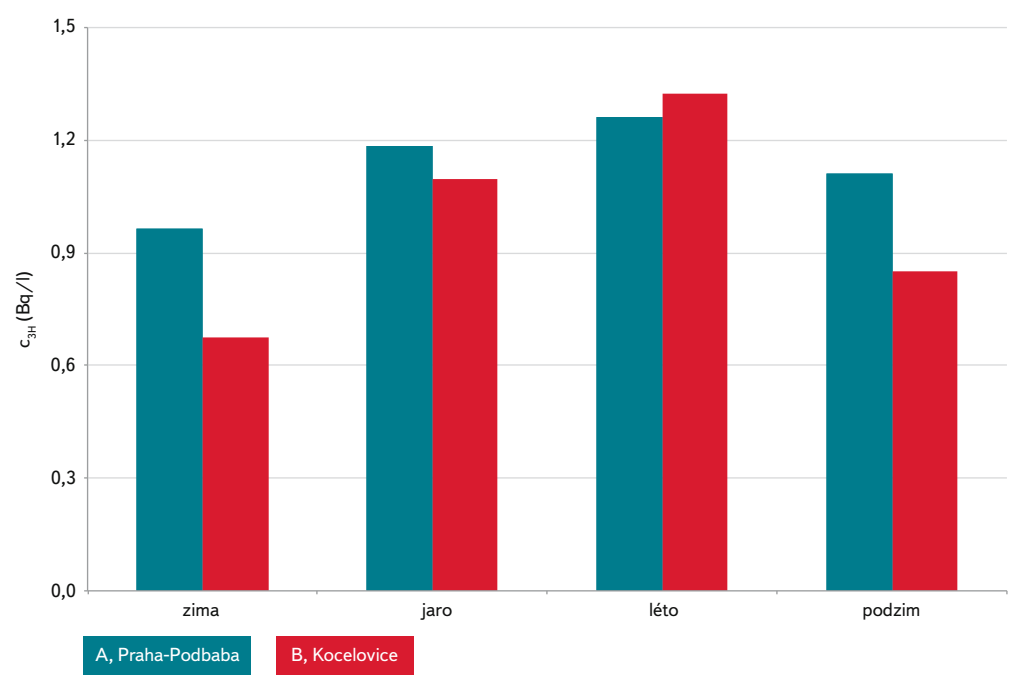

Obr. 5. Průměrné hodnoty (vážené) objemových aktivit tritia ve srážkách pro jednotlivá roční období v období 2010-2017

Fig. 5. Seasonal average tritium concentrations weighted by quantity of precipitation for the period 2010-2017

\section{ZÁVĚR}

S využitím citlivého stanovení včetně elektrolytického nabohacení je možné stanovit velmi nízké objemové aktivity tritia, které mají široké uplatnění např $\checkmark$ oblasti hydrogeologického modelování. Zpřesnění hodnot aktivity tritia přispělo i k redukci rozptylů pozorovaných hodnot objemových aktivit.

Hlavním cílem príspěvku bylo vyhodnotit aktuální úroveň tritia ve srážkách a povrchové vodě na území povodí Labe na profilech prímo neovlivněných výpustmi z jaderných zařizení (především JE Temelín a ÚJV Řež). Zjištěné objemové aktivity na úrovni približně 1 Bq/l odpovídají geografickým podmínkám. Tyto aktivity jsou stále vyšší, než je přirozená úroveň, ale príspěvek tritia ze současných zdrojů začíná převažovat nad tritiem pocházejícím z jaderných testů. Po roce 2001 už není patrný další pokles aktivity tritia ve srážkách tak, jak tomu bylo $v$ predešlém období.

\section{Literatura}

[1] LUCAS, L.L. and UNTERWEGER, M.P. Comprehensive review and critical evaluation of the half-time of tritium. Journal of research of the National Institute of Standards and Technology, 2000, 105, p. 541-549.

\section{[2] GREENWOOD, N.N. a EARNSHAW, A. Chemie prvkü. Praha: Informatorium, 1993.}

[3] UNSCEAR. Effects of ionizing radiation: Report to the general assembly, with scientific annexes, vol. ii: Effects. United Nations, New York, 2000.

[4] GAT, J.R., MOOK, W.G., and MEIJER, H.A.J. Environmental Isotopes in the Hydrological Cycle. Principles and Applocations, vol. 2. Atmospheric Water, IAEA, 2001.

[5] ROZANSKI, K. and GRONING, M. Tritium assay in water samples using electrolytic enrichment and liquid scintillation spectrometry. Quantifying uncertainty in nuclear analytical measurements. IAEA-TECDOC-1401, IAEA, Vienna, 2004.

[6] HANSLÍK, E., JEDINÁKOVÁ-KŘíŽOVÁ, V., BRTVOVÁ, M., et al. Temelín nuclear power plant, South Bohemia - Reference level of hydrosphere, prediction of impact, results from pre-operation period. RADIOPROTECTION, vol. 37, C1, 2002. Proceeding of the International Congress ECORAD 2001, Aix-en-Provence, France.

[7] MORGENSTERN, U., STEWART, M.K., and STENGER, R. Dating of streamwater using tritium in post nuclear bomb pulse world: continuous variation of mean transit time with streamflow. Hydrol. Earth Syst. Sci., 2010, vol. 14, No. 11, p. 2289-2301.

[8] PENZHORN, R.D. Natural and man-made sources of tritium: applications of tritium [Kap.] In: TOSTI, S. and GHIRELLI, N. (eds.) Tritium: Production, Uses and Environmental Impact. New York: Nova Publishers, 2013, p. 339-354, ISBN 978-1-62417-270-0.
[9] TADROS, C.V., HUGHES, C.E., CRAWFORD, J., HOLLINS, S.E., and CHISARI, R. Tritium in Australian precipitation: A 50 year record. J. of Hydrol., 2014, 513, p. 262-273.

[10] PUJOL, L. and SANCHEZ-CABEZA, J. Use of tritium to predict soluble pollutants transport in Ebro river waters (Spain). Environ Pol., 2000, vol. 108, No. 2, p. 257-269.

[11] JURANOVÁ, E., HANSLÍK, E., MAREŠOVÁ, D., KAŠPÁREK, L. a HANEL, M. Doby dotoku tritia v profilech VItava Kořensko, Solenice a Praha-Podoli a Labe Hřensko za období 2008-2015. České Budějovice, 2016.

[12] COX, T., RUTHERFORD, J., KERR, S.C., SMEATON, D., and PALLISER, C. An integrated model for simulating nitrogen trading in an agricultural catchment with complex hydrogeology. J. of environ. manag., 2013, 127, p. 268-277.

[13] GORUR, F.K. and GENC, E. The tritium, deuterium and oxygen-18 isotope levels determination in various waters in Rize and Trabzon. Desalin and Water Treat., 2012, vol. 44, No. 1-3, p. 215-222.

[14] CHAU, N.D., DULINSKI, M., JODLOWSKI, P., et al. Natural radioactivity in groundwater - a review. Isot. Environ. Health Stud., 2011, 47, p. 415-437.

[15] Global Network of Isotopes in Precipitation. The GNIP Database. Dostupné z: http://www-naweb.iaea.org/ napc/ih/IHS_resources_gnip.html

[16] Global Network of Isotopes in Rivers. The GNIRDatabase. Dostupnéz: http://www-naweb.iaea.org/ napc/ih/IHS_resources_gnir.html

[17] TOMÁŠEK, M. a WILHELMOVÁ, L. Dlouhodobý trend a sezónní variace aktivity tritia v povrchových vodách před spuštěním JE Temelín. Vodníhospodárství, 1997, 11, s. 357-362.

[18] IVANOVOVÁ, D. and HANSLÍK, E. Temporal and spatial changes in tritium concentration in the Vltava River basin affected by the operation of Temelín Nuclear Power Plant. Acta Universitatis Carolinae Environmentalica, 2009, vol. 23, No. 1-2, p. 17-31. ISSN 0862-6529.

[19] HANSLIIK, E. and MAREŠOVÁ, D. Case study: Quantification of individual components of tritium balance in the Vltava and Elbe Rivers affected by the operation of Temelín Nuclear Power Plant (Czech Republic) [Kap.] In: TOSTI, S. and GHIRELLI, N. (eds.) Tritium: Production, Uses and Environmental Impact. New York: Nova Publishers, 2013, p. 339-354. ISBN 978-1-62417-270-0.

[20] ČSN EN ISO 9698 Kvalita vod - Stanovení objemové aktivity tritia - Kapalinová scintilační měřicí metoda. ÚNMZ, 2016.

[21] ČSN 757600 Kvalita vod - Stanovení radionuklidů - Obecná ustanovení. ÚNMZ, 2013.

[22] SMITH, J.T. and BERESFORD, N.A. Chernobyl: catastrophe and consequences. New York: Springer, 2005.

[23] MOMOSHIMA, N. and HAYASHI, Y. Meteorologically induced seasonal variation of tritium concentration in rain at Fukuoka, Japan. In: MÖBIUS, S., NOAKES, J.E., SCHÖNHOFER, F. (ed.) Advances in Liquid scintillation spektrometry, 2001, RADIOCARBON, Arizona.

[24] OSMAN, A.A., BISTER, S., RIEBE, B., et al. Radioecological investigation of ${ }^{3} \mathrm{H},{ }^{14} \mathrm{C}$, and ${ }^{129}$ in natural waters from Fuhrberger Feld catchment, Northern Germany. J. of Environ. Radioact., 2016, 165, p. $243-252$

[25] ZAHN, A., BARTH, V., PFEILSTICKER, K., and PLATT, U. Deuterium, oxygen-18, and tritium as a tracers for water vapour transport in the lower stratosphere and tropopause region. J. Atmos. Chem. 1998, vol. 30, No. 1, p. 25-47.

\section{Autoři}

RNDr. Diana Marešová, Ph.D. ${ }^{1}$

凶diana.maresova@vuv.cz

Ing. Eduard Hanslík, CSc.

凶eduard.hanslik@vuv.cz

Ing. Eva Juranová1,2

凶eva.juranova@vuv.cz

\section{Ing. Barbora Sedlářová}

$凶$ barbora.sedlarova@vuv.cz

'Výzkumný ústav vodohospodářský T. G. Masaryka, v. v. i.

2Univerzita Karlova, Přírodovědecká fakulta, Ústav pro životní prostředí

Příspěvek prošel lektorským řízením. 


\title{
DETERMINATION OF LOW LEVEL \\ TRITIUM CONCENTRATIONS FOR \\ TRITIUM TRACING APPLICATIONS
}

\section{MARESOVA, D.'; HANSLIK, E.'; JURANOVA, E. ${ }^{1,2}$;}

SEDLAROVA, B. ${ }^{1}$

'TGM Water Research Institute, p. r. i.

${ }^{2}$ Charles University in Prague, Faculty of Science,

Institute for Environmental Studies

Keywords: tritium - precipitation - surface water -

LSC - electrolytic enrichment

\begin{abstract}
Past tests of nuclear weapons in the atmosphere, nuclear energy facilities and tritium of natural origin are main sources of tritium in the environment. Thanks to its presence in environment and its favourable properties, tritium is used as a radiotracer. Since stopping of atmospheric nuclear tests, tritium in precipitation has been decreasing towards natural levels below $1 \mathrm{~Bq} / \mathrm{L}$ and precise analyses of low level tritium activities are necessary. This paper focuses on tritium development at sites not influenced by any technogenic releases of tritium in Elbe River Basin (Bohemia) in the Czech Republic using liquid scintillation measurement in the period 2001-2017, with electrolytic enrichment in the period 2010-2017.
\end{abstract}

